\title{
FLEXURAL BEHAVIOR AND FAILURE MECHANISM OF NORMAL STRENGTH R.C. BEAMS CONTAINING ALKALI INDUSTRIAL WASTES AND REINFORCED WITH DIFFERENT AMOUNTS OF MAIN STEEL UNDER STATIC LOADING
}

\author{
Rashwan M. M. and Assaf K. A. \\ Civil Engineering Department, Faculty of Engineering, Assiut University, Assiut, \\ Egypt.
}

(Received March 4, 2006 Accepted March 22, 2006)

Modern production of high qualiy concrete is closely connected with wide use of different types of admixtures, which in small doses allow to obtain the required physical, technical, exploitation and economical properties of concrete. Improvement of the mechanical properties of normal strength R.C. beams in flexure by using plasticizing chemical admixtures is becoming on increasing by popular retrofit technique among researchers and engineering world wide. Plasticizing admixtures, which contain in their composition alkali industrial wastes, represent practical interest especially for our local country conditions.

Therefore, the main purpose of the project described in this paper is to give better and full understanding of the flexural behaviour and failure mechanism of normal strength R.C. rectangular beams containing in their compositions alkali wastes and secondary products of oil and cellulose paper industries and reinforced with different amounts of steel under static loading. The main variables studied in this research were: three different types of plasticizing admixtures, which contain in their compositions different amounts of alkali wastes from secondary products of oil and cellulose paper industries, and three different types of beams reinforced with different amounts of tension steel bars(under reinforced-type A, balanced reinforced -type B, and over reinforced - type $C$ ).

The experimental results showed that, the suggested plasticizing admixtures containing amounts of alkali industrial wastes in their compositions have a good effect on increasing the ultimate capacity of under and balanced R.C. beams by about $27 \%$ \& $77 \%$ respectively. Also, they decrease their maximum central deflection by about $20 \%$ \& $18 \%$ respectively compared to the control tested beams. These admixtures, especially type (SM-S) decrease the cracking capacity of under reinforced beams by about $20 \%$ and increased it for balanced reinforced beams by about $40 \%$. They increase factor of safety of tested beams against complete failure by about $90 \%$ for under reinforced, $117 \%$ for balanced reinforced and 19\% for over reinforced beams. The suggested admixtures have a bad influence on the flexural behavior of over reinforced tested beams compared to the control ones.

KEYWORDS: Flexural behavior, admixture, alkali wastes, strength, strain, deflection, concrete, failure mechanism, crack patterns, balanced reinforced, under reinforced section, over reinforced section, ultimate load, cracking load. 


\section{1- INTRODUCTION}

Over the past several years, there has been a concerned research efforts to explore the mechanism effect of chemical plasticizing admixtures, especially organic types, on the mechanical properties of R.C. structures. Increasing the concrete alkali content by adding alkali addition to the mixture water has harmful effects on most mechanical properties (compressive, splitting, direct tensile, and flexure strengths) of concrete [1,2]. Admixtures, which contain in their compositions organic materials with limited doses, represent practical interest especially for our local country conditions. This practical interest attractive more investigators because of their availability and outstanding advantages such as: high compressive and tensile strength of concrete, durable concrete in aggressive environmental conditions, suitable resistance to corrosion, very low cost and not causing epidemic for organism of man $[3,4,5]$.

The organic materials can be obtained from the secondary products and alkali wastes of vegetable oil, chemical synthesis and cellulose paper industries. The action of organic elements on cement paste and concrete mixture is determined by the structure of their molecules and correlation between organic and non-organic particles of their molecules. It is known that, organic elements have the ability of adsorption on the surfaces of cement particles and solid phase. They also take part in formation space, coagulate structure and orientation molecules $[6,7]$. The initial development of producing concrete with organic admixtures technique took place in the USSR laboratories for materials testing and research, which have concentrated on the effect of organic materials on concrete properties since 1981. Many research works have been focused on the application of organic admixtures in the technology of concrete and reinforced concrete structures. Because of their positive influence on the physical and mechanical properties of R.C. elements not only on their early period of hardening, but also for the period of their exploitation in the building site $[4,5]$.

It is known that, the organic materials have not the solubility with water. So, it is necessary to solve these elements with water by using dissolving products before adding them in concrete mixes. In this research the solubility of these elements with water was achieved by using calcium oxide and superplasticizers such as "BVF" and "PVS". Investigations about using complex organic admixtures, which contain in their composition alkali wastes from oil industries, such as (LSM, CLSM, SMP) for the improvement of concrete and reinforced concrete properties were carried out $[6,7,8]$. But, however their effects are not sufficient studied especially for reinforced concrete beams. The mechanical behavior of R.C. beams without admixtures under static and repeated loads was studied $[9,10,11]$. Improvement of the compression zone properties and deformation characteristics of R.C. beams by using complex organic admixtures type "SM- $\mathrm{C}_{1}$ " and "SM- $\mathrm{C}_{2}$ " was studied under static loading $[12,13]$. But, the mechanism effect of organic admixtures, containing alkali industrial wastes from oil and cellulose paper industries, on the flexural behavior, crack patterns and mode of failure of R.C. beams reinforcing with different amounts of steel bars was not enough studied.

So, this paper focuses on the application of new chemical admixtures containing in their compositions alkali wastes from oil and cellulose paper industries, (type SM-S, 
SMP \& CM-B) on flexural behavior and failure mechanism of rectangular R.C. beams of normal strength concrete of $250-300 \mathrm{~kg} / \mathrm{cm}^{2}$ and reinforced with different amounts of steel bars under static loads. Experimental program consists of twelve R.C. rectangular beams to propose the best-suggested admixture effect on the behavior of their flexure, mode of failure and crack patterns.

\section{2- EXPERIMENTAL PROGRAM}

The main aim of this program is to investigate experimentally the flexural behavior and failure mechanism of different groups of normal strength R.C. rectangular beams modified with the suggested new types of organic admixtures under static load. The experimental approach in this study consisted of testing twelve rectangular R.C. beams under static load. The main variables studied were:

- Different types of suggested organic admixtures, which were fabricated in the laboratory and contained in their composition alkali wastes of oil and cellulose paper industries (type: SM-S, CM-B \& SMP).

- Different amounts of main steel reinforcement (under reinforced- type A, balanced reinforced-type $\mathrm{B}$, over reinforced - type $\mathrm{C})$.

All groups of beams, with and without admixtures, were identical in size, $12 \times 28 \mathrm{~cm}$ rectangular section and overall length $220 \mathrm{~cm}$. All beams were tested at 28 days curing age under four points of loading on an effective span of $200 \mathrm{~cm}$ and with shear to effective depth ratio " $\mathrm{a} / \mathrm{d}=2.8$ ".

All beams were classified to three groups depending on the amount of main steel reinforcement. Each group consisted of four beams depending on the type of fabricated organic admixtures (SM-S\& CM-B) and control organic-plasticizing admixture (type SMP). The beams have the same amount of compression reinforcement of $2 \$ 13 \mathrm{~mm}$, and having the same amount of closed stirrups of $10 \phi 6 \mathrm{~mm} / \mathrm{m}$. The first group of beams was reinforced by $2 \$ 13 \mathrm{~mm}$ as tension reinforcement (under reinforced section). The second group was reinforced by $4 \$ 13 \mathrm{~mm}$ as tension reinforcement (balanced reinforced). The third group was reinforced by $6 \$ 13 \mathrm{~mm}$ as tension reinforcement (over reinforced). Details of reinforcement are shown in Fig. 1.

\section{3- MATERIALS}

\subsection{Technique Of Preparing And Producing The Suggested Admixtures}

The experimental technique for preparing and producing the suggested organic admixtures were carried out by the method explained in the previous works $[6,7,8,12$, 13]. The suggested organic admixtures type "SM-S", "CM-B" and "SMP' are consisted of the secondary products and alkali wastes $(\mathrm{pH}=9)$ of vegetable oil and cellulose paper industries, Calcium oxide "CaO", Superplasticizers"BVF", \& "PVS", and water.

The effect of composition and parameters of combination of different elements on the quality of the suggested admixtures was carried out by using the previous explained methods [6,7]. The composition and correlation of components of the proposed admixtures by weight from their solid particles are shown in Table $\mathbf{1 .}$ 

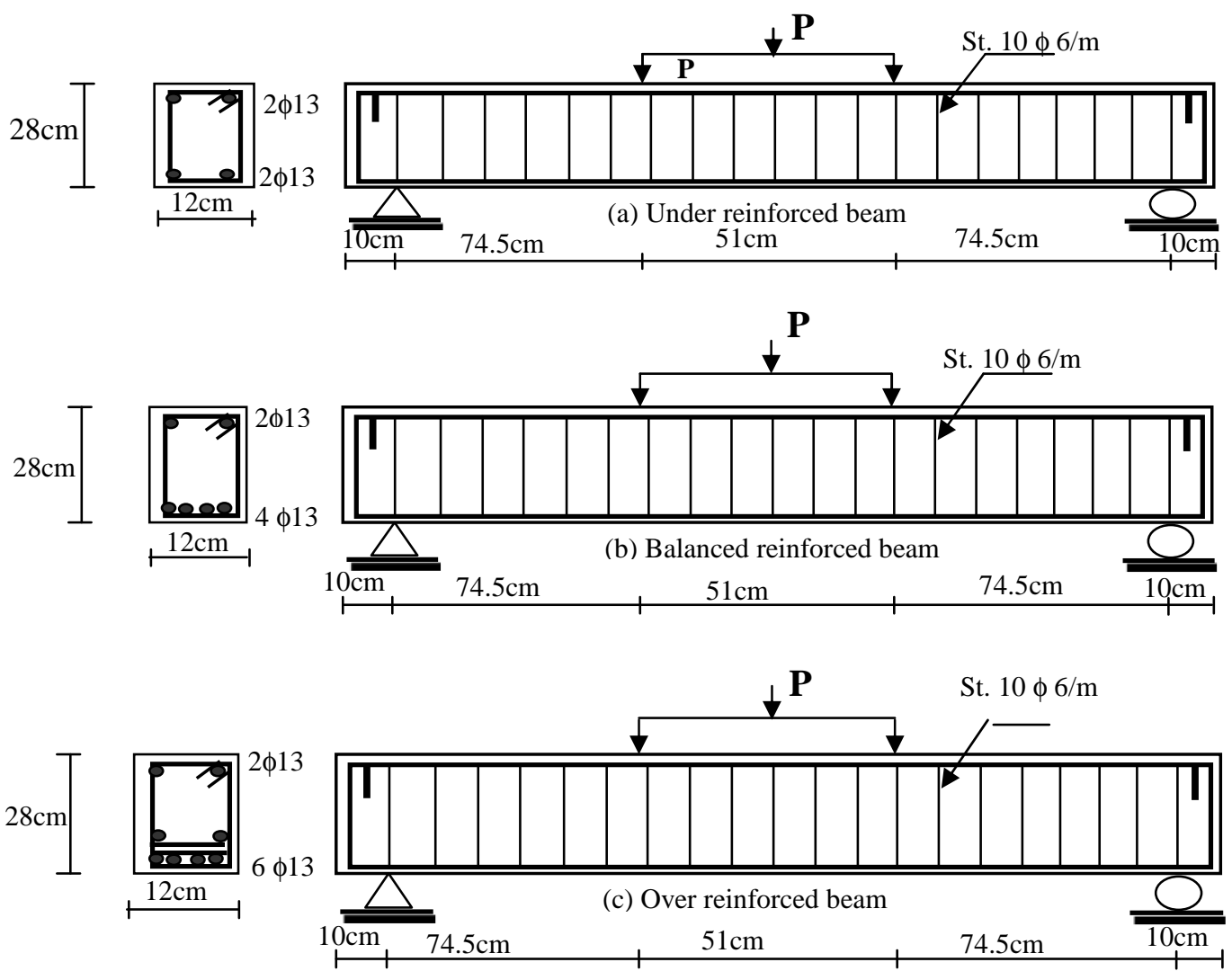

Fig. 1: Details of reinforcement and load configuration for tested beams.
(a) Group type"A" (B $\left., B_{2}, B_{3}, B_{4}\right)$,
(b) Group type"B" $\left(\mathrm{B}_{5}, \mathrm{~B}_{6}, \mathrm{~B}_{7}, \mathrm{~B}_{8}\right)$

(c) Group type"C" (B, $\left.B_{10}, B_{11}, B_{12}\right)$

\section{2 Normal Strength Concrete}

Concrete mixes were used to produce normal strength concrete having 28-days cubic compressive strength of $250-300 \mathrm{~kg} / \mathrm{cm}^{2}$. Optimum dose of each admixture, at which occurs maximum values of compressive strength was determined by the previous methods $[6,7,8]$. The influence of the value of optimum dose and type of each admixture on the compressive strength of concrete after 28-days curing age are shown in Table 2.

Four different concrete mixes were used. Slump of about $5.5 \mathrm{~cm}$ was constant for all types of mixes. The influence of the value of the optimum dose and type of the suggested admixtures on the compressive strength for all types of mixes were studied and obtained by the method explained by $[6,7,8]$. Details of concrete mixes and their compressive strength after 28 and 210 days hardening in fresh water are shown in Table 2.

Ordinary Portland cement of specific gravity 3.2 was used (Assiut cement). Coarse aggregate used was $20 \mathrm{~mm}$ maximum nominal size and fineness modulus 7.2. Local natural sand of fineness modulus 2.4 was used as a fine aggregate. 
Table 1: Composition and correlation of components of the organic admixtures.

\begin{tabular}{|c|c|c|}
\hline Type of admixture & Components of the admixture & $\begin{array}{c}\text { Correlation of } \\
\text { components \% by } \\
\text { weight }\end{array}$ \\
\hline "SMP" (control) & $\begin{array}{l}\text { 1-Alkali wastes of vegetable oil } \\
\text { industries (liquid solution } \mathrm{pH}=9.5 \text { ), } \\
\text { 2-Calcium oxide "CaO" } \\
\text { 3-Superplasticizer "BVF, and } \\
\text { 4-Water }\end{array}$ & $\begin{array}{c}11.17 \\
2.79 \\
3.35 \\
82.69\end{array}$ \\
\hline $\begin{array}{c}\text { "SM-S" } \\
\text { (Suggested) }\end{array}$ & $\begin{array}{l}\text { 1-Alkali wastes of vegetable oil } \\
\text { industries (liquid solution, pH=9.5), } \\
\text { 2-calcium oxide "CaO" } \\
\text { 3- Superplasticizer "PVS “, and } \\
\text { 4-Water }\end{array}$ & $\begin{array}{l}8.00 \\
0.67 \\
1.87 \\
89 .\end{array}$ \\
\hline $\begin{array}{c}\text { "CM-B" } \\
\text { (suggested ) }\end{array}$ & $\begin{array}{l}\text { 1-Alkali wastes of cellulose paper } \\
\text { industries (liquid solution, pH=9), } \\
\text { 2- Calcium oxide "CaO" , } \\
\text { 3-Superplasticizer "BVF ", and } \\
\text { 4-Water }\end{array}$ & $\begin{array}{c}8.00 \\
0.67 \\
1.76 \\
89.57\end{array}$ \\
\hline
\end{tabular}

Table 2: Details of concrete mixes and their compressive strengths " $\mathrm{Fc}$ " at optimum dose of the suggested admixtures.

\begin{tabular}{|c|c|c|c|c|c|c|c|c|c|}
\hline \multirow{2}{*}{$\begin{array}{l}\text { Mix } \\
\text { No. }\end{array}$} & \multicolumn{3}{|c|}{$\begin{array}{l}\text { Mix component, } \\
\mathrm{Kg} / \mathrm{m}^{3}\end{array}$} & \multicolumn{2}{|c|}{ Suggested Admixtures } & \multirow[b]{2}{*}{ W/c } & \multirow{2}{*}{$\begin{array}{c}\text { Slump of } \\
\text { the cone, } \\
\mathrm{cm}\end{array}$} & \multicolumn{2}{|c|}{$\mathrm{Fc}, \mathrm{Kg} / \mathrm{Cm}^{2}$} \\
\hline & C & $S$ & $\mathrm{G}$ & Type & $\begin{array}{c}\text { Optimum dose, } \\
\% \text { by weight of } \\
\text { cement }\end{array}$ & & & \begin{tabular}{|c|}
28 \\
days
\end{tabular} & $\begin{array}{c}90 \\
\text { days }\end{array}$ \\
\hline 1 & 350 & 670 & 1285 & ----- & 0.00 & 0.437 & 5.5 & 267 & 278 \\
\hline 2 & 350 & 675 & 1289 & CM-B & 0.25 & 0.420 & 5.5 & 325 & 341 \\
\hline 3 & 350 & 677 & 1298 & SM-S & 0.25 & 0.415 & 5.5 & 320 & 350 \\
\hline 4 & 350 & 679 & 1301 & SMP & 0.50 & 0.410 & 5.5 & 328 & 348 \\
\hline
\end{tabular}

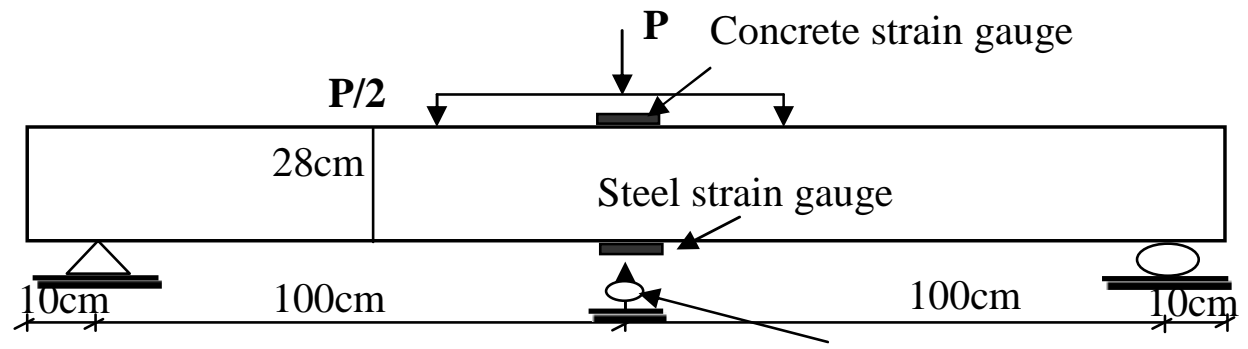

Deflectometer

Fig. 2: Method of measuring deformation at the mid span of R.C. tested beams. 


\section{3 Steel Reinforcement}

The steel bars used as tension and compression reinforcement of beams was a normal strength mild plain bars having diameter $8 \mathrm{~mm}$ and yield strength $2880 \mathrm{~kg} / \mathrm{cm}^{2}$ and stirrups $6 \mathrm{~mm}$ diameter with yield stress $2790 \mathrm{~kg} / \mathrm{cm}^{2}$.

\section{4 Test Procedure}

The testing machine (EMS 60-tons) was used. Acting load was applied at $74.5 \mathrm{~cm}$ from the support as shown in Fig. 1. Each beam was loaded gradually keeping the rate of loading constant. The increment of loading equal 0.5 ton and was constant for a period equal 5 minutes. All readings of maximum strain and deflection of concrete, at the mid span, of the of different types of R.C. beams under static loading were measured as shown in Fig. 2. Also, the maximum strain of tension reinforcement, at the mid span, was measured for all types of beams by using strain indicator. The values of maximum deflection, maximum strain of concrete and maximum strain of main reinforcement was determined at $85 \%$ from the failure load. The time of appearance of initial cracking and consumed time of testing until failure was recorded to determine the effect of these admixtures on the factor of safety of tested beams against failure.

\section{4- RESULTS AND DISCUSSIONS}

Test results of the twelve R.C. beams (three groups) are presented in Tables $3 \& \mathbf{4}$. The tables also include the predicted ultimate capacities of the tested beams using the ultimate simplified method of CP8110 [15].

Table 3: Cracking \& ultimate load and measured ultimate deformations of concrete for all tested beams.

\begin{tabular}{|c|c|c|c|c|c|c|c|c|}
\hline \multirow{2}{*}{$\begin{array}{l}\text { Type of } \\
\text { beams }\end{array}$} & \multirow{2}{*}{$\begin{array}{l}\text { No.of } \\
\text { Beams }\end{array}$} & \multirow{2}{*}{$\begin{array}{c}\text { Type of } \\
\text { Admixture, } \\
\text { dose, \% }\end{array}$} & \multirow{2}{*}{$\begin{array}{l}\mathrm{Fc}_{28}, \\
\mathrm{Kg} / \mathrm{cm}^{2}\end{array}$} & \multicolumn{2}{|c|}{$\begin{array}{c}\text { ultimate load, } \mathrm{Pu} \\
\text { tons }\end{array}$} & \multirow{2}{*}{$\begin{array}{l}\text { cracking } \\
\text { load, ton }\end{array}$} & \multirow{2}{*}{$\begin{array}{c}\text { Max, } \\
\text { con.defl. } \\
\delta, \mathrm{mm}\end{array}$} & \multirow{2}{*}{$\begin{array}{c}\text { Max, } \\
\text { concr. } \\
\text { strain } \\
\text { €cx } 10^{-3}\end{array}$} \\
\hline & & & & Pu exp. & Pu th. & & & \\
\hline \multirow{4}{*}{$\begin{array}{c}\text { Under } \\
\text { reinforced } \\
\text { (Group A) }\end{array}$} & $\mathrm{B}_{1}$ & Control & 267 & 5.5 & 4.254 & 3.0 & 9.27 & 3.95 \\
\hline & $\mathrm{B}_{2}$ & CM-B & 325 & 5.5 & 4.305 & 2.0 & 9.01 & 3.60 \\
\hline & $\mathrm{B}_{3}$ & SM-S & 320 & 7.0 & 4.311 & 2.0 & 7.49 & 3.7 \\
\hline & $\mathrm{B}_{4}$ & SMP & 328 & 4.0 & 4.309 & 2.0 & 8.2 & 4.95 \\
\hline \multirow{4}{*}{$\begin{array}{l}\text { Balanced } \\
\text { reinforced } \\
\text { (Group B) }\end{array}$} & $\mathrm{B}_{5}$ & Control & 267 & 6.5 & 7.93 & 2.5 & 7.6 & 1.7 \\
\hline & $\mathrm{B}_{6}$ & CM-B & 325 & 6.5 & 8.138 & 2.5 & 6.83 & 1.55 \\
\hline & $\mathrm{B}_{7}$ & SM-S & 320 & 11.5 & 8.161 & 3.0 & 6.32 & 2.70 \\
\hline & $\mathrm{B}_{8}$ & SMP & 328 & 12.0 & 8.151 & 3.50 & 6.50 & 2.60 \\
\hline \multirow{4}{*}{$\begin{array}{c}\text { Over } \\
\text { reinforced } \\
\text { (Group C) }\end{array}$} & $\mathrm{B}_{9}$ & Control & 267 & 16.0 & 11.03 & 7.0 & 7.7 & 2.75 \\
\hline & $\mathrm{B}_{10}$ & CM-B & 325 & 15.0 & 11.50 & 7.0 & 8.5 & 6.8 \\
\hline & $\mathrm{B}_{11}$ & SM-S & 320 & 15.0 & 11.55 & 6.50 & 5.51 & 4.15 \\
\hline & $\mathrm{B}_{12}$ & SMP & 328 & 15.50 & 11.53 & 7.0 & 7.95 & 3.55 \\
\hline
\end{tabular}


Table 4: Ultimate longitudinal strain of steel reinforcement and degree of warening against failure for all tested beams.

\begin{tabular}{|c|c|c|c|c|c|c|c|}
\hline $\begin{array}{l}\text { Type of } \\
\text { beams }\end{array}$ & $\begin{array}{c}\text { No.of } \\
\text { Beams }\end{array}$ & $\begin{array}{c}\text { Type of } \\
\text { Admixture }\end{array}$ & $\begin{array}{c}\text { Max, steel. } \\
\text { strain } \\
\text { €s } 10^{-3}\end{array}$ & $\begin{array}{c}\text { Time of } \\
\text { initial } \\
\text { cracking, } \\
\text { T1, min }\end{array}$ & $\begin{array}{l}\text { Time } \\
\text { until } \\
\text { failure, } \\
\text { T2, min }\end{array}$ & $\begin{array}{c}\mathrm{T} 2-\mathrm{T} 1 \\
\min \end{array}$ & $\begin{array}{c}\text { degree.of } \\
\text { warening } \\
\text { against } \\
\text { failure }\end{array}$ \\
\hline \multirow{4}{*}{$\begin{array}{c}\text { Under } \\
\text { reinforced } \\
\text { (Group A) }\end{array}$} & $\mathrm{B}_{1}$ & Control & 1.88 & 15 & 30 & 15 & 1.00 \\
\hline & $\mathrm{B}_{2}$ & CM-B & 2.2 & 12.0 & 33 & 21 & 1.40 \\
\hline & $\mathrm{B}_{3}$ & SM-S & 1.83 & 12.5 & 41 & 28.5 & 1.90 \\
\hline & $\mathrm{B}_{4}$ & SMP & 2.30 & 12 & 27 & 15 & 1.00 \\
\hline \multirow{4}{*}{$\begin{array}{c}\text { Balanced } \\
\text { reinforced } \\
\text { (Group B) }\end{array}$} & $\mathrm{B}_{5}$ & Control & 1.73 & 13 & 37 & 24 & 1.00 \\
\hline & $\mathrm{B}_{6}$ & CM-B & 1.43 & 15 & 40 & 25 & 1.04 \\
\hline & $\mathrm{B}_{7}$ & SM-S & 1.96 & 18 & 70 & 52 & 2.17 \\
\hline & $\mathrm{B}_{8}$ & SMP & 1.76 & 20 & 71 & 51 & 2.12 \\
\hline \multirow{4}{*}{$\begin{array}{c}\text { Over } \\
\text { reinforced } \\
\text { (Group C) }\end{array}$} & $\mathrm{B}_{9}$ & Control & 1.68 & 42 & 90 & 48 & 1.00 \\
\hline & $\mathrm{B}_{10}$ & CM-B & 1.53 & 40 & 93 & 53 & 1.10 \\
\hline & $\mathrm{B}_{11}$ & SM-S & 1.73 & 37 & 94 & 57 & 1.19 \\
\hline & $\mathrm{B}_{12}$ & SMP & 1.56 & 41 & 94 & 53 & 1.10 \\
\hline
\end{tabular}

\section{1 Cracks And Mode Of Failure Of The R.C. Tested Beams}

\section{1. 1 Cracks and mode of failure of under R.C. Tested beams (type A)}

The crack propagation of the under R.C. control tested beams (B1-without admixture \& B4- with the control admixture SMP) was observed in the critical tension zone at the maximum moment, which initiated at the center of the beam. The first crack was a wide vertical tension crack at the mid span by a load 2.5 tons. By increasing the applied load, several secondary vertical and diagonal cracks were observed in the tension zone starting from the bottom and propagated up, to the top surface of the compression zone of the tested beam at the loading points, by about $85 \%$ from the total depth. The length and width of cracks increased rapidly with the increase of the applied load up to failure $\left(\mathrm{P}_{\mathrm{f}}=5.5 \mathrm{t}\right)$ with one vertical wide main crack at the mid span in the tension zone and different secondary cracks distributed at a length $85 \%$ of effective span of the beam. The major crack was formed at the same region of the first initial cracks as shown in Fig. 3. The final mode of failure for these tested beams was flexural failure with crushing of the concrete cover at the mid span in the tension zone.

The initiation and propagation of the first crack of beams B2\&B3 with the suggested admixtures CM-B \& SM-S was observed in the critical tension zone at the maximum moment (Fig. 3), which initiated at the center of the beam. The first crack was a narrow vertical tension crack at the mid span by a load 2.0 tons. By increasing the applied load, several secondary vertical and diagonal cracks were observed in the tension zone. These cracks started from the bottom surface and propagated up, to the top surface of the compression zone of the tested beam at the loading points, by about $80 \%$ from the total depth. The length, number and width of cracks increased slowly with the increase of applied load up to failure with two vertical wide main crack at the mid span in the tension zone and different secondary cracks distributed at a length = 

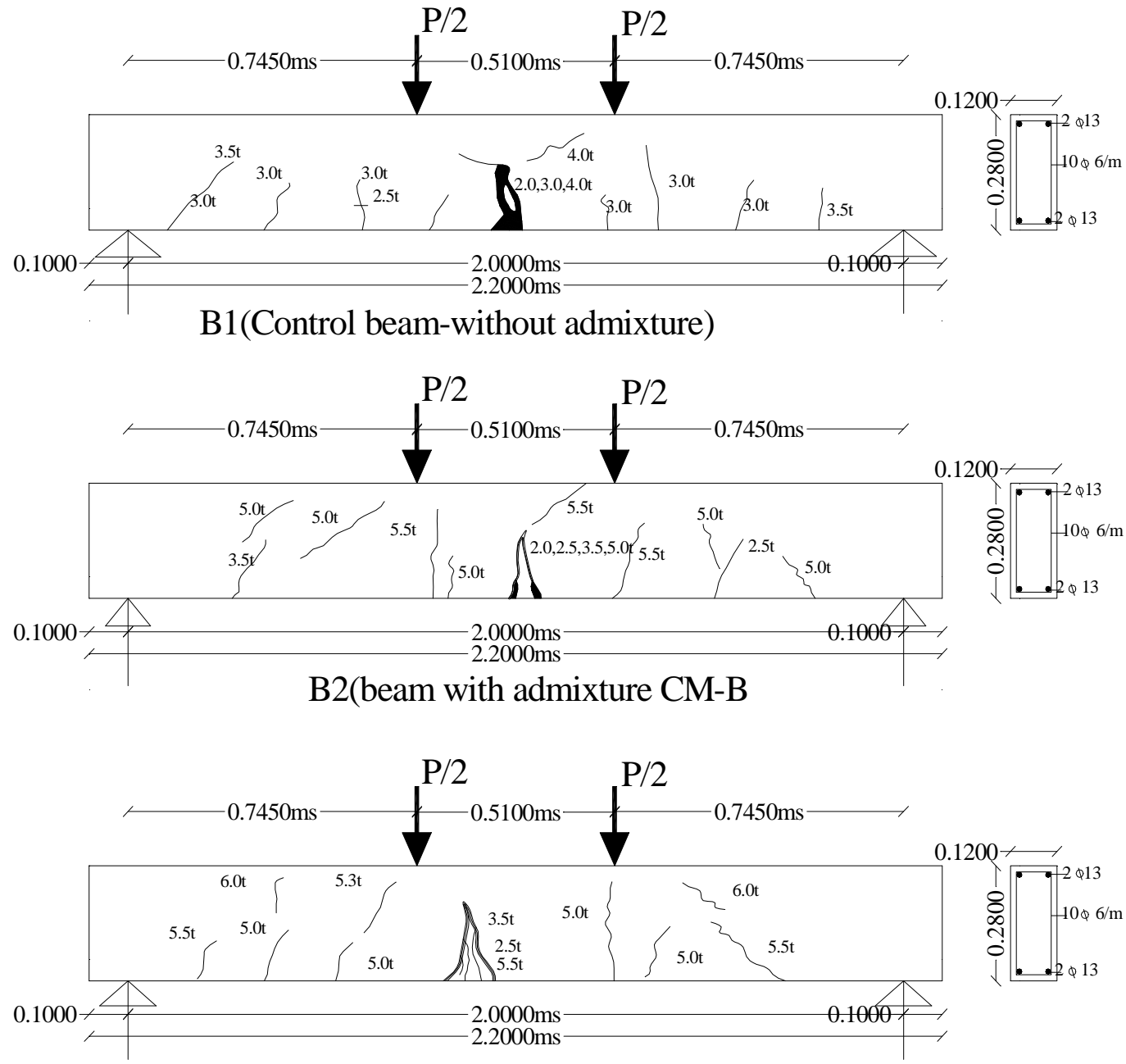

B3(beam with admixture SM-S)

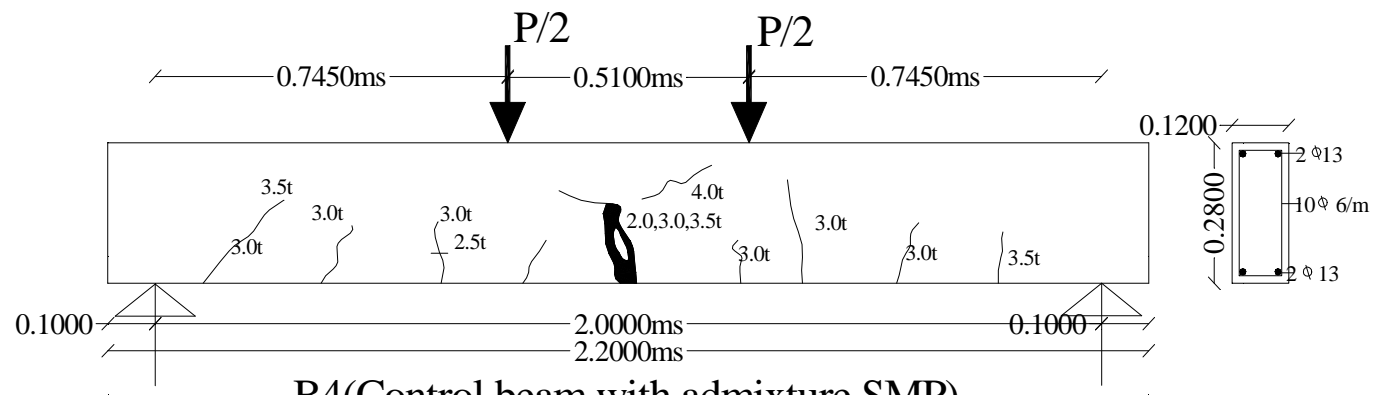

B4(Control beam with admixture SMP)

Fig. 3: Crack patterns and modes of failure for under reinforced tested beams (Group A). 
$75 \%$ from effective span of the beam. But, the width of cracks of beam "B2" is smaller than that occurred with the control beams "B1 \&B4". The final mode of failure for these tested beams was flexural failure plus delimitation of the concrete cover at the mid span in the tension zone. It is necessary to notice that, the admixtures SM-S \& CM-B reduce the width of major crack and number of secondary cracks in the tension zone compared to the control beam. The positive influence of alkali wastes plus superplasticizers may explain this phenomenon due to the improvement of the microstructure of the hardened concrete and bond between cement paste and filling materials, which increase its tensile strength.

\section{1 . 2 Cracks and mode of failure of balanced R.C. tested beams (type B)}

Crack patterns for balanced R.C. tested beams are shown in Fig. 4. For the control beam (B5), cracks were observed in the critical tension zone of the maximum moment and also in the shear zone. The first crack is a narrow vertical and diagonal tension crack at the mid span by a load 2.5 tons. By increasing the applied load, propagation of vertical and inclined cracks in the tension zone were observed. Also, several secondary diagonal cracks were initiated in the shear zones. They started from the bottom and propagated up, to the top surface of the compression zone of the tested beam at the loading points. The length and width of cracks increased rapidly with the increase of applied load up to failure $\left(\mathrm{P}_{\mathrm{f}}=6.5 \mathrm{t}\right)$ with one vertical wide main crack at the mid span in the tension zone and different secondary cracks. The final mode of failure was flexural shear failure with crushing of the compression zone at the mid span accompanied by a sudden high explosive sound.

For the beam with the admixture "CM-B" (B6), cracks were observed in the critical tension zone of the maximum moment and also in the shear zone. The first crack is a narrow vertical and diagonal tension crack at the mid span by a load 3 tons. As the applied load increases, several secondary vertical and diagonal regular cracks were observed in the tension and shear zones. They started from the bottom and propagated up vertically and diagonally to the top surface of the compression zone of the tested beam near the loading points to about $85 \%$ from the total depth. The length and width of cracks increased slowly with the increase of applied load up to failure $\left(\mathrm{P}_{\mathrm{f}}=6.5 \mathrm{t}\right)$ with one vertical narrow main crack at the mid span in the tension zone and different secondary cracks. The final mode of failure was flexural shear failure with crushing of the compression zone at the mid span of the beam without high explosive sound.

For the beam with the admixture "SM-S" (B7), cracks were observed in the critical tension zone only at the middle third and some of them in the shear zone. The first crack was observed in the tension zone only at the middle third by a load 3 tons. As the applied load increases, several secondary vertical and inclined irregular cracks were initiated and concerned in the middle third of the tension zone and some diagonal cracks in the shear zones. They started from the bottom and propagated up to the top surface of the compression zone of the tested beam near the loading points to about $90 \%$ from the total depth. The length and width of cracks increased slowly with the increase of applied load up to failure $\left(\mathrm{P}_{\mathrm{f}}=11.5 \mathrm{t}\right)$. These irregular cracks were distributed over the middle third of the tension zone and some of them over the shear zone of the beam. The final mode of failure was flexural shear failure without crushing of the compression zone at the mid span. This means that, the admixture SM-S reduces the number and width of cracks than the admixture "CM-B. 


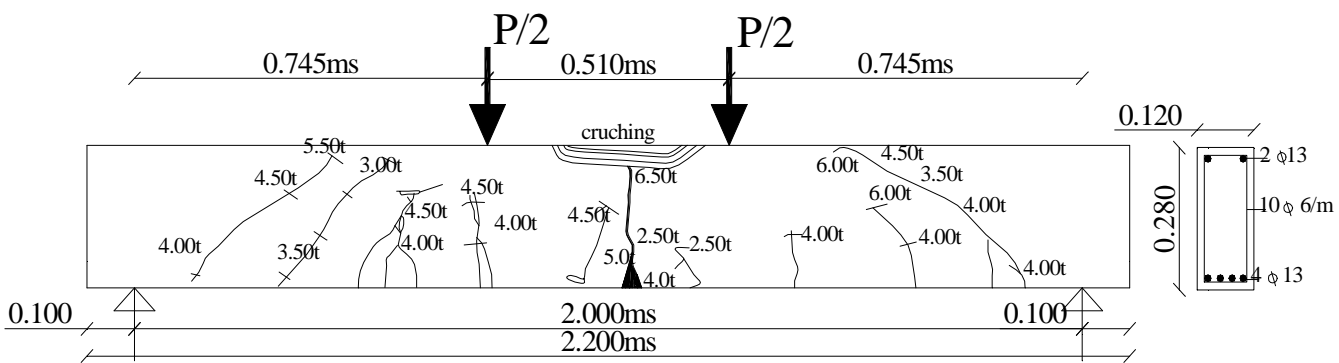

B5(Control beam-without admixture)

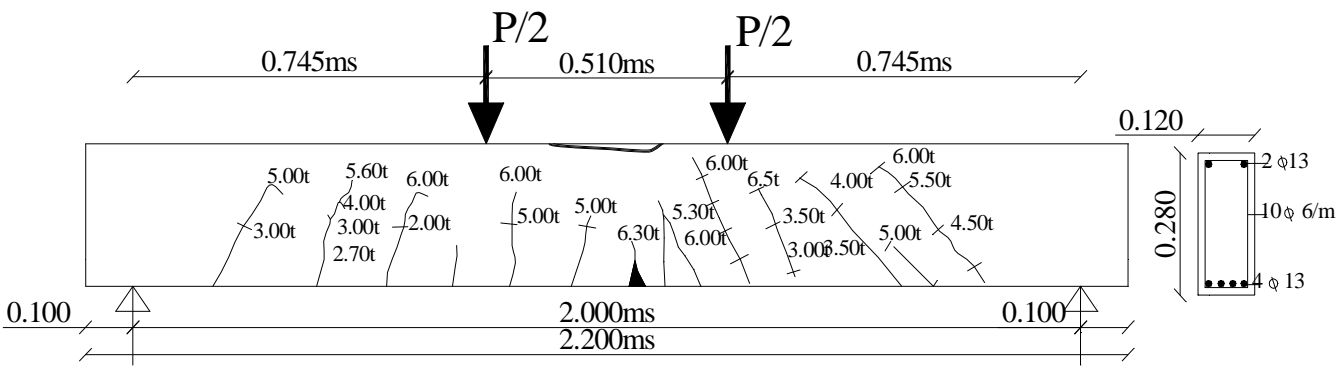

B6(beam with admixture CM-B)
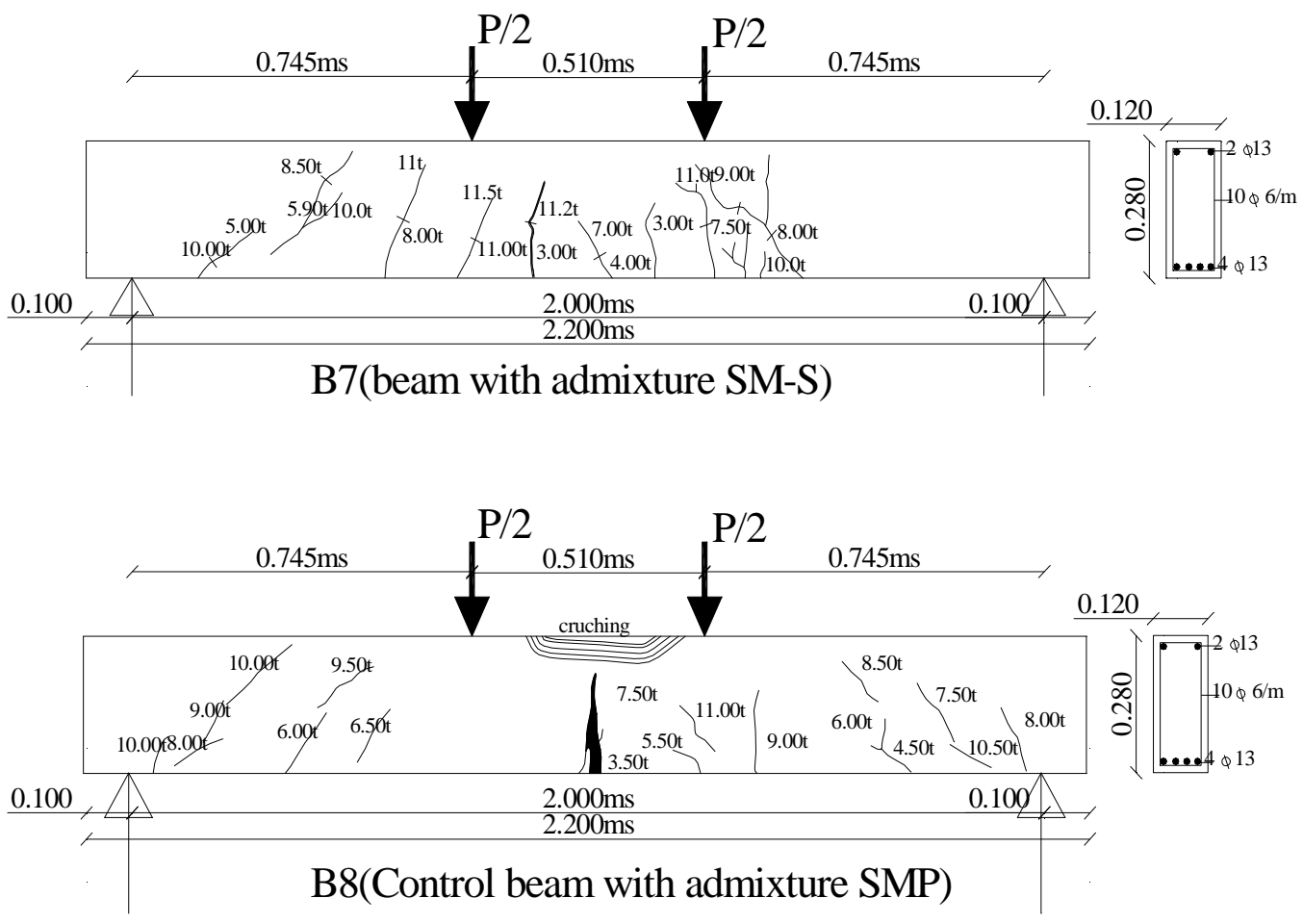

ш

Fig. 4: Crack patterns and modes of failure for balanced reinforced tested beams (Group B). 
For the beam (B8) with the control admixture SMP, cracks were observed in the critical tension zone and also in the shear zone. The first crack was a vertical tension crack at the mid span and initiated by a load 3.5 tons. By increasing the applied load, several secondary vertical and diagonal cracks were propagated in the tension and shear zones. They started from the bottom and propagated up, to the top surface of the compression zone of the tested beam at the loading points.

The number, length and width of cracks increased rapidly with the increase of applied load up to failure $\left(\mathrm{P}_{\mathrm{f}}=12 \mathrm{t}\right)$ with one vertical wide main crack at the mid span in the tension zone and different secondary cracks distributed over the whole effective span of the beam. The final mode of failure was flexural shear failure with crushing of the compression zone at the mid span accompanied by a sudden high explosive sound. This means that, the control admixture SMP increases the brittleness of the beam due to its effect on increasing actual compressive stresses than the allowable which leads to the crushing of the compression zone of the tested beam.

\section{1. 3 Cracks and mode of failure of over R.C. tested beams (type C)}

Crack propagations and modes of failure for over R.C. tested beams with different admixtures are shown in Fig. 5. For the control beam (B9- without admixture), cracks were initiated in the critical tension zone of the maximum moment with small numbers and also in the shear zone. The first crack is a narrow vertical tension crack at the mid span by a load 7 tons. By increasing the applied load to 13 tons, several secondary more diagonal cracks were observed in the shear zones. They started from the bottom and propagated up, diagonally and some of them vertically, to the top surface of the compression zone of the tested beam at the loading points. The length and width of cracks increased rapidly with the increase of applied load up to failure $\left(P_{f}=15.5 t\right)$ with one vertical wide main crack at the mid span in the tension zone and different secondary diagonal cracks distributed over the whole effective span of the beam. The final mode of failure was flexural shear compression failure with crushing of the compression zone at the mid span of the beam accompanied by a sudden high explosive sound.

For over R.C. beam with the admixture "CM-B" (B10), irregular cracks were observed with a large numbers in the shear zone of the beam and a little of them in the critical tension zone at the middle third. The first crack is a narrow diagonal crack in the shear zone by a load 7 tons. As the applied load increases up to failure $\left(\mathrm{P}_{\mathrm{f}}=15\right.$ tons $)$, these irregular crack propagated up diagonally from the bottom to the top surface of the compression zone of the tested beam near the loading points and distributed over the whole effective span of the beam. The final mode of failure was shear compression failure with crushing of the concrete cover at the mid span in the compression zone without high explosive sound.

For over R.C. beam with the admixture "SM-S" (B11), regular diagonal cracks were initiated with a large numbers, than that of admixture "CM-B", in the shear zone of the beam and a little of them in the critical tension zone at the middle third. The first crack is a narrow diagonal crack in the shear zone near the support by a load 7 tons. As the applied load increases up to failure $\left(\mathrm{P}_{\mathrm{f}}=15\right.$ tons $)$, these regular cracks propagated up diagonally from the bottom to the top surface of the compression zone of the tested 


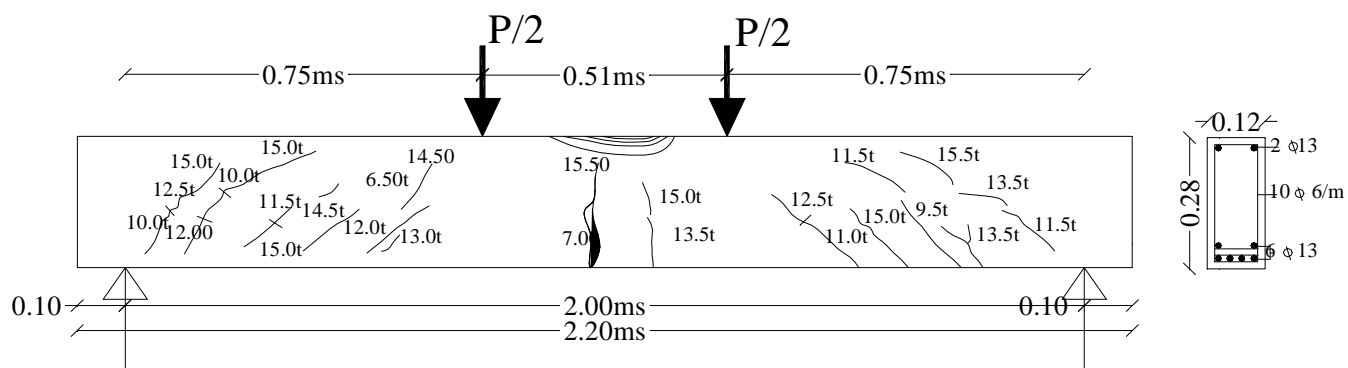

B9(Control beam-without admixture)
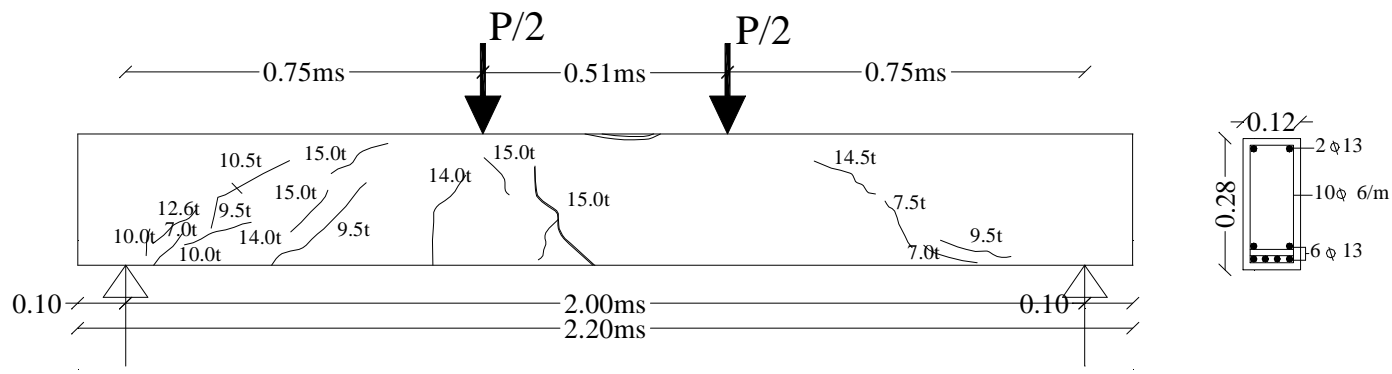

B10(beam with admixture CM-B)
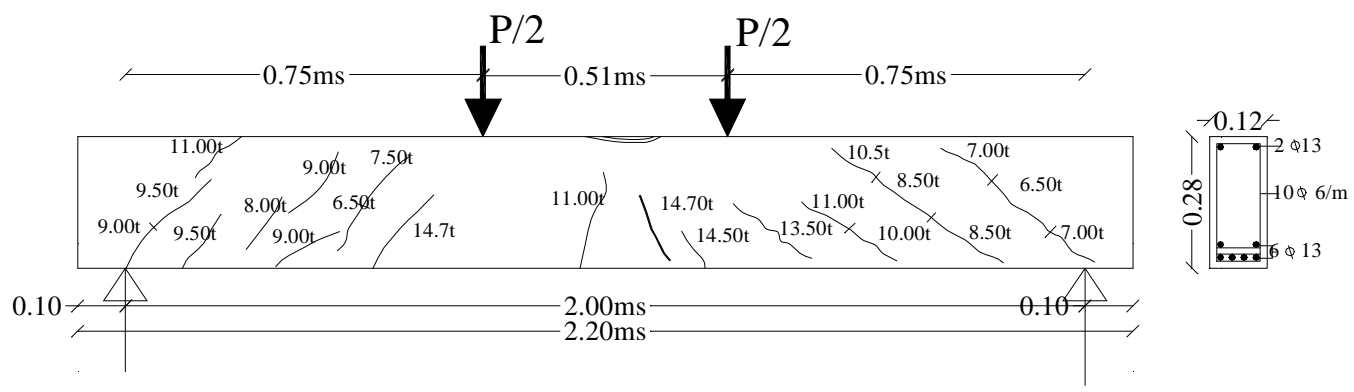

B11(beam with admixture SM-S)
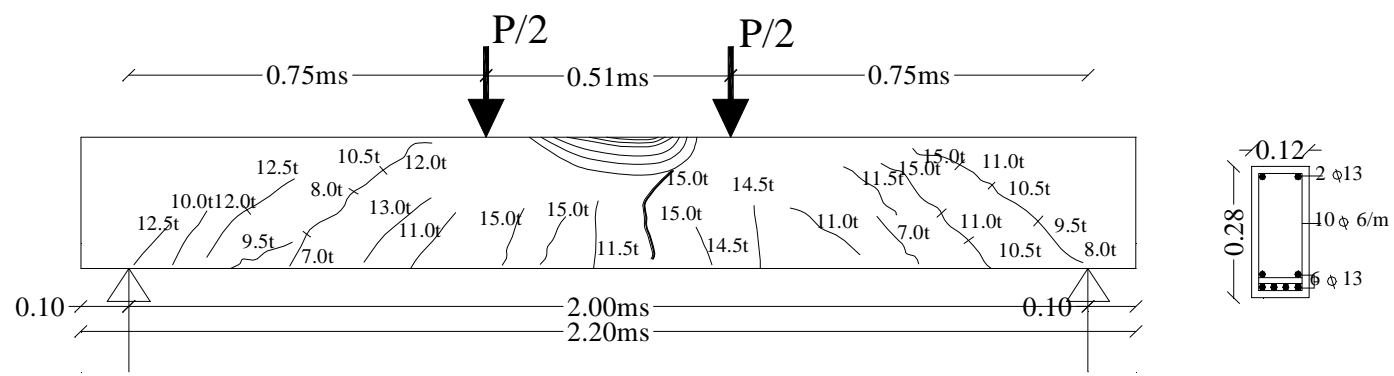

B12(Control beam with admixture SMP)

Fig. 5: Crack patterns and modes of failure for over reinforced tested beams (Group C). 
beam near the loading points. They were distributed over the whole effective span of the beam with one vertical crack in the tension zone at the middle third and many diagonal cracks in the shear zones. The final mode of failure was shear flexural failure with crushing of the concrete cover at the mid span in the compression zone without high explosive sound.

For over R.C. beam with the control admixture "SMP" (B12), cracks propagation were similar to that occurred with the suggested admixture "SM-S" except the number of vertical cracks in the middle third of the beam was more and wide. The final mode of failure was shear compression failure with crushing of the concrete cover at the mid span in the compression zone accompanied by a sudden failure.

The positive effect of the suggested admixtures especially type "SM-S" on reducing wide, length and number of cracks may be explained by its influence on increasing the bond between cement paste and filling materials, depth of the compression zone of the tested beams and regulating the micro porous structure of the hardened concrete. This leads to producing more dense and homogeneous concrete, which consequently reduces deformation and increases the allowable compressive stresses to become nearly the actual compressive stresses. So, the failure of the compression zone of this type of beams changes from crushing of the compression zone with sudden high explosive sound into crushing only of the concrete cover in the compression zone without sudden failure.

\section{2 Cracking And Ultimate Loads}

Tables 3 \& 4 and Fig. 6 show the experimental cracking and ultimate loads and measured deformations of the different types of R.C. beams with and without admixtures under static load.
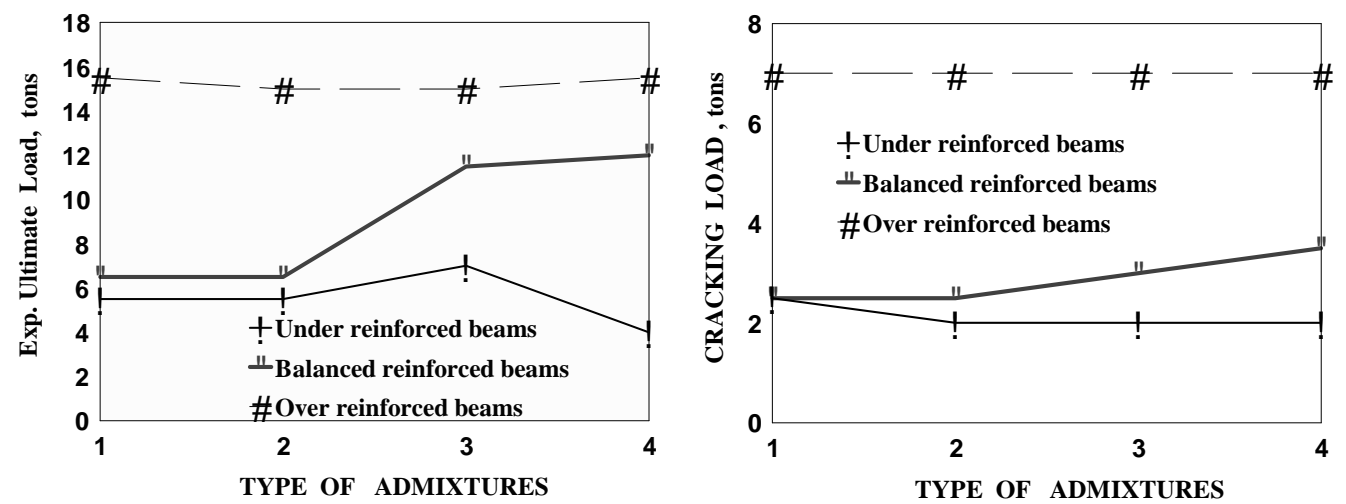

Fig. 6: Cracking and ultimate loads of different types of R.C. tested beams as affected by each type of organic suggested admixtures.

1) Control beams without admixtures (B1, B5 \& B9),

2) Beams with admixture "CM-B" (B2, B6 \& B10),

3) Beams with admixture "SM-S" (B3, B7 \& B11) and

4) Beams with control admixture "SMP" (B4, B8 \& B12) 


\section{2. 1 Cracking and ultimate loads of under R.C. beams}

For under R.C. tested beams, the suggested organic admixtures have the same bad effect on cracking load compared to the control beam. They decrease it by about $20 \%$ from 2.5 to 2 tons. But, tested beam (B3) with admixture "SM-S" showed an increase in its ultimate load of $27 \%$ over that of reference beam (B1). Tested beam (B4) with the control admixture "SMP" showed a decrease in its ultimate load of $27 \%$ less than that of reference beam (B1).

For balanced R.C. tested beams, the suggested organic admixture "CM-B" has no effect on cracking or ultimate load compared to the control beam (B5). But, beam (B7) with admixture "SM-S" showed an increase in its cracking and ultimate loads of 20 \&77 \%, respectively over that of reference beam (B5). Tested beam (B8) with the control admixture "SMP" showed an increase in its cracking and ultimate load of 40 \& $84 \%$ over than that of reference beam (B5).

For over R.C. tested beams, the suggested organic admixture have no any effect on cracking load compared to the control beam (B9). But, tested beams (B10 \& B11) with admixture "CM-B \& SM-S" showed a decrease in their ultimate load of about $3 \%$ less than that of reference beams. Tested beam (B12) with the control admixture "SMP" showed the same values of cracking and ultimate load of reference beam (B9).

So, it is clear that the positive influence of the suggested admixtures, especially type "SM-S", on increasing cracking and ultimate capacity of under and balanced R.C. tested beams compared to the control ones. This may be explained by the effect of these admixtures with alkali wastes on regulating the micro porous structure of the hardened concrete, which produces more dense and homogeneous structure. Consequently, amount, number, length and width of internal cracks decrease which increase the cracking and ultimate capacity of tested beams. But, in the case of over R.C. beams, the influence of these admixtures is neglected due to the effect of large amount of tension steel bars in the beam. Which leads to the large decrease of the depth of compression zone of concrete section more than that of its increase with the admixtures. This consequently implies to producing maximum deformations and strains at the top fibers of the compression zone area. So, the actual concrete compressive strength became more greater than the allowable values, which leads to the sudden failure and crushing of the compression zone of beam section before yielding of steel.

\section{2. 2 Calculation of the maximum flexural capacity of R.C. tested beams}

The maximum flexural capacity of each type of beams with and without admixtures is estimated according to CP8110 [15] and shown in Table 3. For "CP8110", maximum concrete compressive strain of 0.0035 is considered. The concrete stress distribution is a rectangular over the entire compression zone and equals to $0.6 \mathrm{Fcu}$. The centroid is at half the depth of the compression zone. The maximum flexural capacity of the studied beams is calculated. The comparison between the predicted load carrying capacity of each beam and that obtained experimentally is shown in Table $\mathbf{3}$ and Fig. 7.a. The comparison shows that, there is a significant difference between the calculated values and the experimental values of the ultimate load. Actual ultimate load of under R.C. beams with and without admixtures is greater than that calculated by CP 8110 by about 
$28 \%$ for beam (B2- with admixture CM-B) and $63 \%$ for beam (B3- with admixture SM-S). For balanced R.C. beams, actual ultimate load is smaller than that predicted by about $22 \%$ \& $25 \%$ for beam B5 \& B6 respectively. For beams (B7 - with SM-S \&B8with SMP), actual ultimate load increases than that predicted by about $41 \& 47 \%$ respectively. But, the actual ultimate load of over R.C. beams with and without admixtures is greater than that predicted by CP8110 by about $30 \%$.

(a)

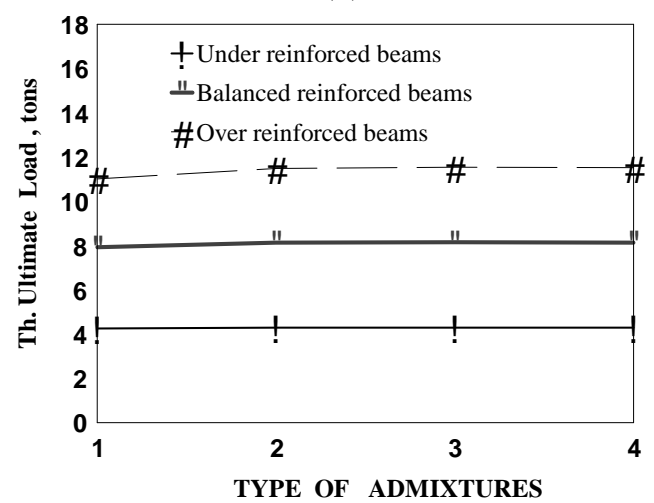

(b)

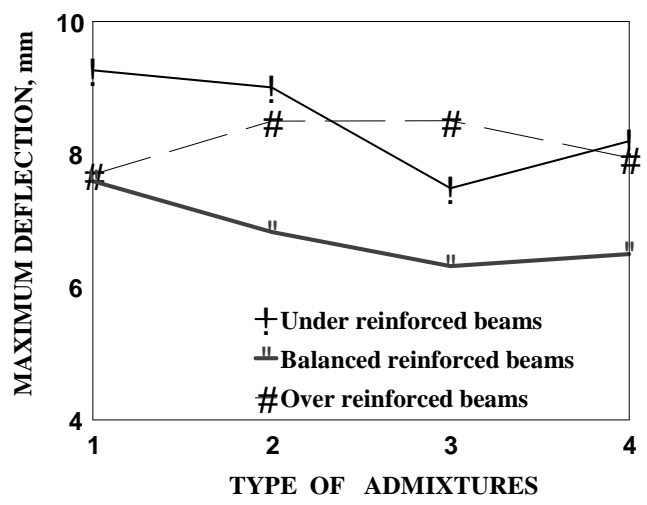

Fig. 7: Theoretical ultimate loads and maximum central deflection of different types of R.C. tested beams as affected by each type of suggested admixtures.

(a) theortetical ultimate load versus type of admixtures,

(b) maximum central deflection versus type of admixtures

1) Control beams without admixtures (B1, B5 \& B9),

2) Beams with admixture "CM-B" (B2, B6 \& B10),

3) Beams with admixture "SM-S" (B3, B7 \& B11) and

4) Beams with control admixture "SMP" (B4, B8 \& B12)

\section{3 Measured Deformations}

Generally, using organic plasticizing admixtures in the technology of concrete increases the stiffness of the section of R.C. beams and hence, decreases the indicated measured deformations [12, 13]. This also noticed for the R.C. beams of normal strength concrete of $250-300 \mathrm{~kg} / \mathrm{cm}^{2}$, which were tested in this program.

\section{3. 1 Experimental maximum deflection of R.C. tested beams}

Table 3 and Fig. 7.b show the effect of suggested admixtures on the maximum central deflection, at $85 \%$ from the failure load, of different types of R.C. tested beams. They show that, the addition of suggested admixtures in the concrete mix has a clear effect on reducing maximum deflection of under and balanced R.C. beams. But, these admixtures have a bad influence on the value of central deflection of over R.C. tested beams. The maximum deflection of tested beams with these admixtures decreases by a value ranged from 10 to $20 \%$ for under reinforced and from 11 to $17 \%$ for balanced reinforced beams compared to the control beams. The large effect on decreasing maximum deflection occurs with admixture "SM-S". Maximum deflection of over R.C. beams with the suggested admixtures increases by a value ranged from 3 to $10 \%$ depending on the type of admixture and compared to the control tested beam. 


\section{3. 2 Maximum concrete strain of R.C. tested beams}

Table 3 and Fig. 8.a show the influence of the suggested admixtures on the maximum compressive strain of concrete, at $85 \%$ from the failure load, at mid span of different types of R.C. tested beams. Maximum compressive concrete strain of under R.C. beams (B2 \& B3) with the suggested admixture decreases by about $9 \%$ compared to the control-tested beam. But, the control admixture "SMP" increases concrete strain of beam (B4) by about 25\% compared to the control beam (B1). For balanced R.C. tested beams, the suggested and control admixtures (SM-S \&SMP) increase maximum concrete strain by about $59 \& 53 \%$, respectively. But, the admixture (CM-B) decreases it by about $9 \%$ compared to the control beam (B5). For over R.C. tested beams, the admixtures (CM-B\&SM-S) increase maximum concrete strain by about $28 \& 11 \%$, respectively. But, control admixture (SMP) decreases it by about $6 \%$ compared to the control tested beam (B9).

\section{3. 3 Maximum steel strain of R.C. tested beams}

Table 4 and Fig. 8.b show the influence of the suggested admixtures on the maximum strain of main steel, at $85 \%$ from the failure load, at mid span of different types of R.C. tested beams. Maximum steel strain of under R.C. beams (B2 \& B4) with the admixture (CM-B\&SMP) increases by about $17 \& 20 \% \%$ respectively. But, it decreases by about $3 \%$ for beam (B2) with admixture (SM-S) compared to the control beam (B1). For balanced R.C. beams, the admixture (SM-S) increases maximum steel strain by about $13 \%$. But, admixture (CM-B) decreases it by about $17 \%$ compared to the control beam (B5). For over R.C. beams, the admixtures (CM-B \&SMP) decrease the maximum steel strain by about $9 \& 7 \%$, respectively. But, admixture (SM-S) increases it by about $3 \%$ compared to the control beam (B9).

(a)

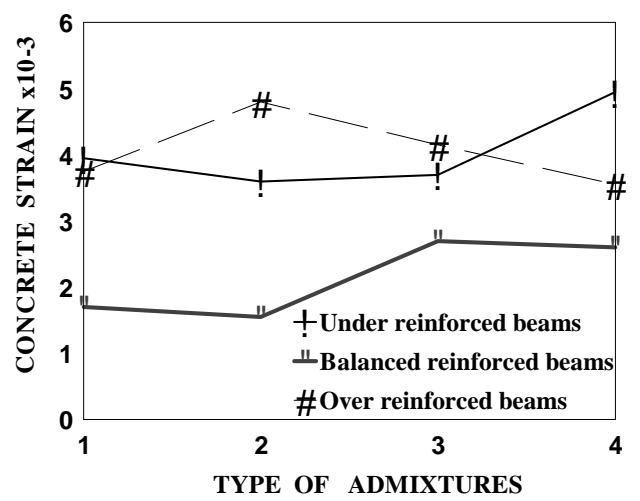

(b)

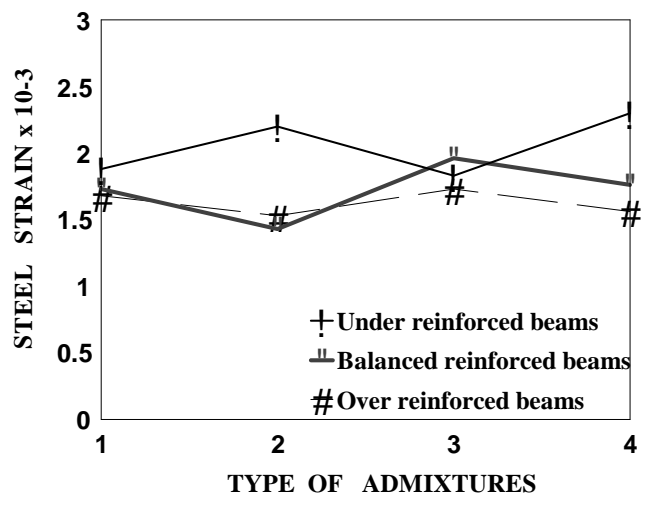

Fig. 8: Maximum central concrete and steel strain of different types of R.C. tested beams as affected by each type of suggested admixtures.

(a) maximum concrete compressive strain versus type of admixtures,

(b) maximum central strain of main steel versus type of admixtures

1) Control beams without admixtures ( $B 1, B 5$ \& B9),

2) Beams with admixture "CM-B" (B2, B6 \& B10),

3) Beams with admixture "SM-S" (B3, B7 \& B11) and

4) Beams with control admixture "SMP" (B4, B8 \& B12) 
The effect of admixture (SM-S) on decreasing maximum steel strain is expected for under and over reinforced tested beams and not expected for balanced types. Because this admixture decreases the maximum deflection of these types of beams compared to the reference beam. But, the effect of admixture (CM-B) on decreasing maximum steel strain is expected for balanced reinforced tested beams and not expected for over reinforced types. This is explained by the influence of the amount of main steel and amount of alkali wastes in each admixture on changing depth of the compression zone of tested beams, which affected on the value of compressive and tensile stresses of the beam.

\section{4 Calculation Of The Degree Of Warning Of Tested Beams Against Complete Failure}

The degree of warning of any member against complete failure may be assumed as the consumed time from the appearance of its initial cracking until complete failure. So, Table 4 and Figs. 9.a \& 9.b show the effect of different admixtures on the consumed time until failure and factor of safety against failure for each type of tested beams. The degree of warning against failure for each beam was calculated as the ratio between consumed time from cracking until failure of this beam and that of control tested beam and calculated from the following equation:

Consumed time from cracking until failure of any beam

Degree of warning $=$

Consumed time from cracking until failure of control beam

(a)

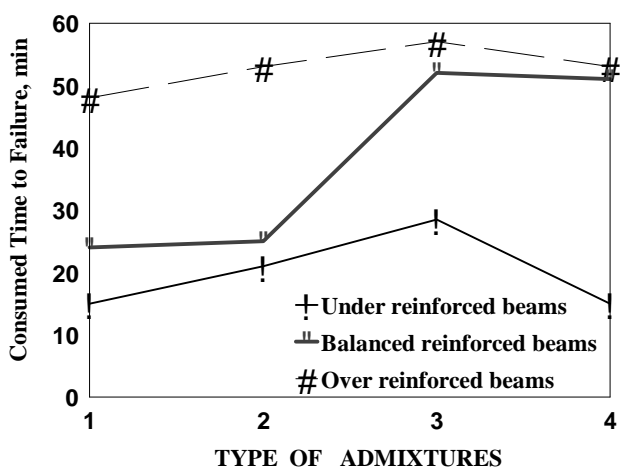

(b)

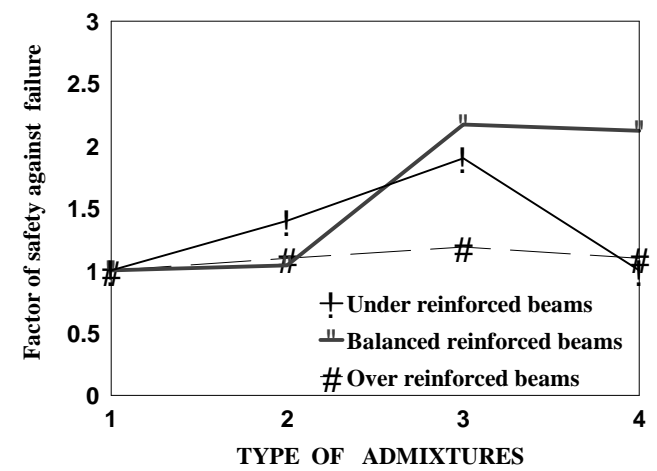

Fig. 9: Consumed time from appearance of cracking to failure and factor of safety against failure of different types of R.C. tested beams as affected by each type of suggested admixtures.

(a) Consumed time from appearance of cracking to failure versus type of admixture,

(b) Degree of warning against complete failure versus type of admixture,

1) Control beams without admixtures (B1, B5 \& B9),

2) Beams with admixture "CM-B" (B2, B6 \& B10),

3) Beams with admixture "SM-S" (B3, B7 \& B11) and

4) Beams with control admixture "SMP" (B4, B8 \& B12) 
It is clear that, the suggested admixtures (SM-S \&CM-B) increase factor of safety of R.C. tested beams against failure by about $90 \%$ \& $40 \%$ for under reinforced types, 117 $\& 4 \%$ for balanced reinforced types and by about $19 \& 10 \%$, respectively for over reinforced types compared to the control ones. This may be explained by their positive influence on increasing bond forces between cement paste and filling materials in the concrete mix and decreasing the amount of macro pores and capillary pores in the hardened concrete. Consequently, length and width and propagation of internal cracks reduced for these tested beams, which increased their ultimate capacity against failure.

\section{CONCLUSIONS}

Based on the results of the experiments carried out on normal strength R.C. beams containing in their compositions alkali wastes from oil and cellulose paper industries and reinforced with different amounts of main steel, the following conclusions can be drawn out:

1- Ultimate strength, stiffness, ductility, cracks propagation and mode of failure of the different types of R.C. tested beams are significantly affected by the suggested admixtures and the amount of main steel reinforcement.

2- The suggested admixtures (SM-S \&SM-B) increase degree of warning of R.C. tested beams against failure by about $90 \%$ \& $40 \%$ for under reinforced types, 117 $\& 4 \%$ for balanced reinforced types and by about $19 \& 10 \%$, respectively for over reinforced types compared to the control ones.

3- The suggested admixtures especially type SM-S changed cracks of R.C. tested beams from several widely spaced and large width cracks in case of control beams to many more closed spaced narrowed cracks.

4- The final mode of failure of R.C. tested beams with admixtures (SM-S\& CM-B) was flexural failure plus separation of the concrete cover at the mid span in the tension zone for under reinforced beams. And it was flexural shear failure without crushing of the compression zone at the mid span for balanced types. But, it was shear compression failure with crushing of the concrete cover at the mid span in the compression zone without high explosive sound for over reinforced beams.

5- The final mode of failure of control tested beams was flexural failure with crushing of the concrete cover at the mid span in the tension zone for under reinforced beams. But, it was flexural shear failure with crushing of the concrete cover at the mid span in the compression zone accompanied by a sudden high explosive sound for balanced and over reinforced types.

6- The suggested organic admixture "CM-B" has no any effect on cracking or ultimate load For balanced R.C. tested beams. But, tested beam with admixture "SM-S" showed an increase in its cracking and ultimate load of 20 \& $77 \%$, respectively over than that of reference beam. Also, tested beam with the control admixture "SMP" showed an increase in its cracking and ultimate load of 40 \& 84 $\%$ over than that of reference beam.

7- Over R.C. tested beam with the suggested and control admixtures showed nearly the same values of cracking and ultimate load of reference beam. But, for under R.C. tested beams, these admixtures have no any enhancement on cracking and ultimate load compared to the control beam. 
8- Maximum flexural capacity of tested R.C. beams with and without suggested admixtures is greater than that calculated by CP8110 by about $63 \%$ \& $28 \%$ for under reinforced and by about $30 \%$ for over reinforced respectively. For balanced R.C. beams, it is smaller than that calculated by about $22 \%$ \& $25 \%$ for control beam \& beam with admixture CM-B, respectively. But, for beams with admixtures SM-S \& SMP, it increases than that calculated by CP8110 by about $41 \& 47 \%$ respectively.

9- The addition of suggested admixtures in the concrete mix has a clear effect on reducing maximum deflection and maximum compressive concrete strain at mid spans of under and balanced R.C. tested beams. But, these admixtures have no any enhancement on the value of central deflection of over R.C. tested beams. The large effect occurs with admixture (SM-S) \&.(CM-B).

\section{REFERENCES}

[1] N. Smaouia, M. A. Bérubé, B. Fournierc, B. Bissonnetted and B. Durand, "Effects of alkali addition on the mechanical properties and durability of concrete", Cement and Concrete Research, vol. 35, ISSUE 2, February 2005, pp. 203-212.

[2] Saeed Ahmad Ataullah and Karamet Ali, " Effect of water reducing admixtures on the properties of concrete", $29^{\text {th }}$ Conference on Our world in Concrete and Structures, 25-26 August 2004.

[3] F. Colangelo, M. Marroccoli, R. Cioffi, “ Properties of Self-levelling concrete made with industrial wastes", RILEM Publications-PRO 40, Materials and Structures, 2005.

[4] Hegerovitsh, M.E., soloviev, V.E., and Tomashpolske, A.D., “ Complex admixture for concrete mixes", A.C. No. 769212, USSR, Pub in B.E., No. 2, 1981.

[5] Batrakov V.G., Falekman V.R., and Venogradof U.M., "Perspective of producing and using admixtures for concrete and reinforced concrete", Journal of concrete and Reinforced concrete, No., 4, Moscow, 1989.

[6] Rashwan, M.M., "Improvement of the properties of concrete with hydrophopizing admixtures in hot and dry weathering conditions", $\mathrm{Ph} . \mathrm{D}$. thesis Eng - Akad., Alma-Ata,1995.

[7] Rashwan, M.M., "Study of the possibility of producing new complex hydrophobizing admixtures for improvement of the cement materials properties “, Bulletin of the faculty of Engineering, Assiut University Vol .24, No.2, July 1996.

[8] Rashwan, M.M. and Sadeek, R.A., "Mechanical behavior of R.C. Columns As affected by a new complex hydrophobizing plasticizing admixture 'SMP', Bulletin of the faculty of Eng., Assiut University, Vol.27, No.1, January, 1999.

[9] Megahid, A., "Effect of Lateral intersection and mode of loading on R.C. Flexural beams," bulletin of the faculty of Engineering, Assiut university, V.77, No.2, January-February, 1980.

[10] Assaf, K.A., "Behaviour of reinforced concrete Beams of L section under static and repeated loads “, M. Sc. thesis, Assiut University, Assiut, 1986. 
[11] Taylor, H.P.T, “ The Fundamental Behavior of Reinforced Concrete Beams”, ACI publication sp. 42-13, shear in Reinforced Concrete Volume I, PP. 43-77, 1974.

[12] Rashwan M.M., Assaf K.A., " Improvement of the compression zone properties of R.C. beams by using complex non-Traditional admixtures", bulletin of the faculty of Engineering, Assiut university, V.29, No.2, May 2001.

[13] Rashwan M.M., Assaf K.A., " Deformation characteristics of R.C. beams affected by using complex non-Traditional admixtures", Journal of Engineering Sciences, Assiut university, Vol.31, No.1, pp. 51-68, January 2003.

[14] Monica Prezzi, Paulo J.M. Monteiro, and Garrison Sposito, “ Alkali- Silica Reaction - Part 2: The effect of chemical admixtures”, ACI Materials Journal, January- February 1998.

[15] BSI, "British Code of Practice for Structure use of Concrete", CP110: Part 1, 1972.<smiles></smiles>

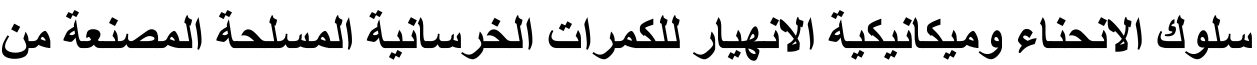

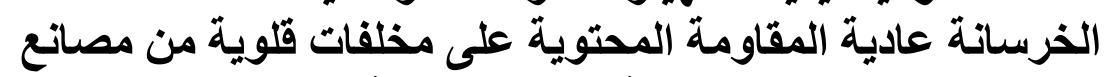

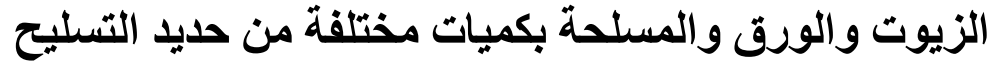
الرئيسي تحت التحميل الاستاتيكي

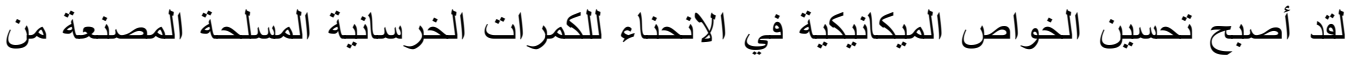
الخرسانة عادية المقاومة باستخدام الإضافات الكيميائية الملدنة للخلطة الخرسانية في زيادة زيادة مستمرة وذلك نتيجة لسهولة تكنولوجيا استخدامها بين الباحثين والمهندسين علي مستوى العالم.

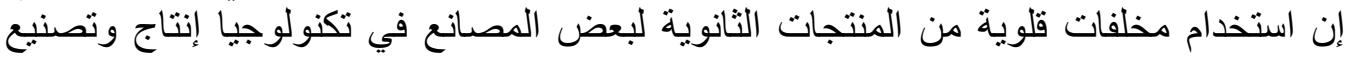
إضافات كيميائية ملدنة للخلطة الخرسانية ومحسنة لخو اص الخرسانة يمثل در اسة علمية و عملية شيقة خاصة من الناحية الاقتصادية و البيئية. ولهذا فإن الغرض الرئيسي من هذا البحث هو إعطاء أفضل وأحسن فهم متكامل عن سلوك الانحناء وميكانيكية الانهيار للكمرات الخرسانية المسلحة المصنعة من الخرسانة العادية المقاومة المداء

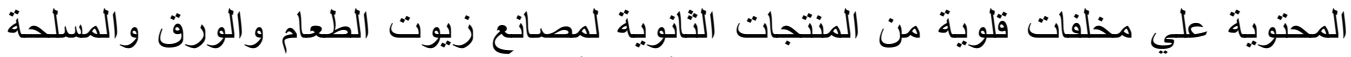
بكميات مختلفة من حديد التسليح الرئيسي تحت تأثير الأحمال الاستاتيكية. إن المتغير ات ات الرئيسية

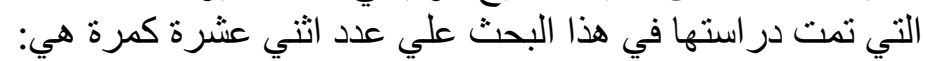

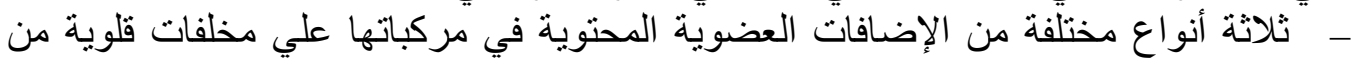

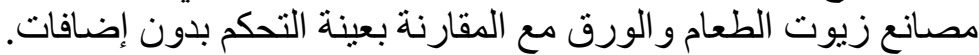
- ثناثة أنواع مختلفة من الكمرات الخرسانية المسلحة بكميات مختلفة من حديد التسليح

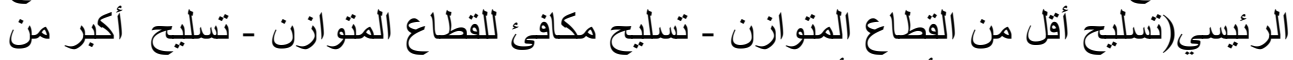
القطاع المتوازن) تحت تأثير الأحمال الاستاتيكية.

$$
\text { لقد أوضحت نتائج الاختبار ات المعملية ما يلي: }
$$

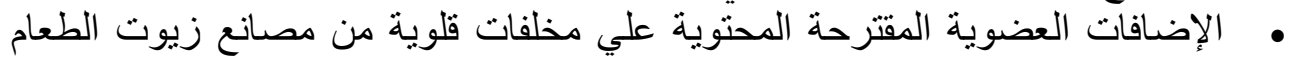

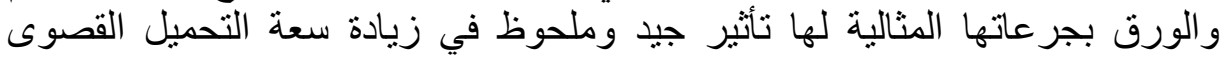




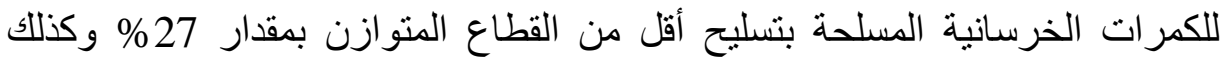

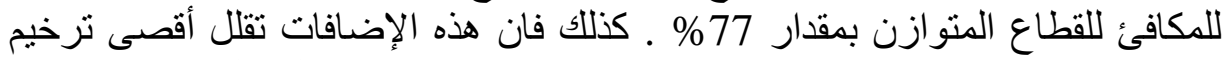

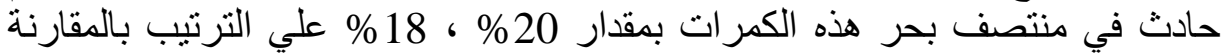

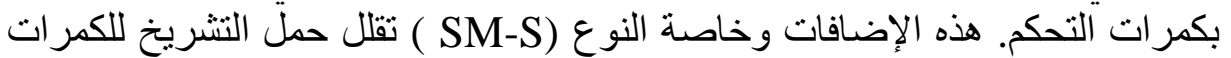

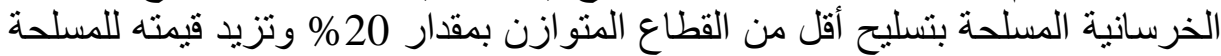

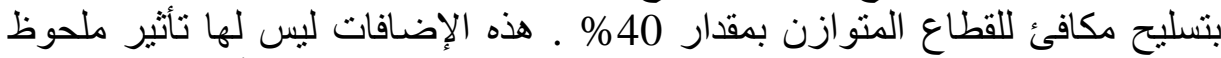

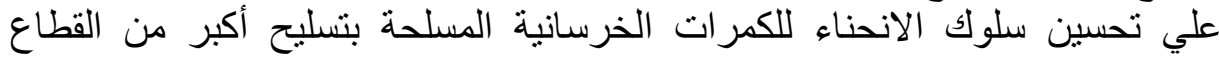

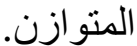

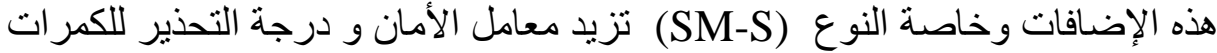

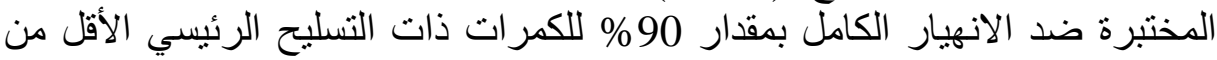

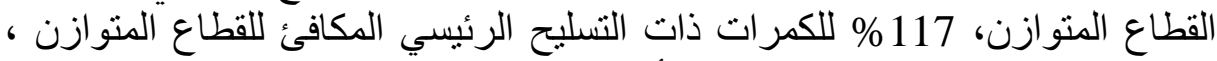

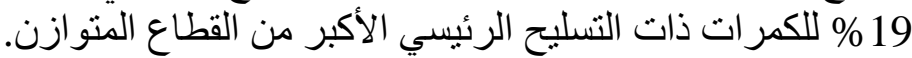

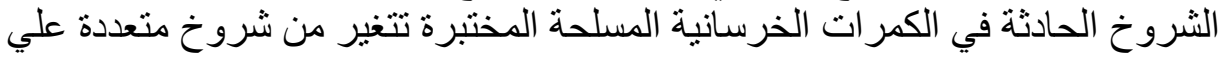

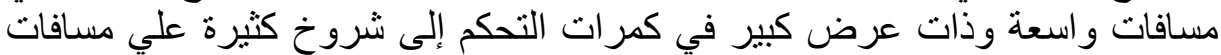

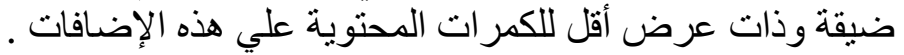

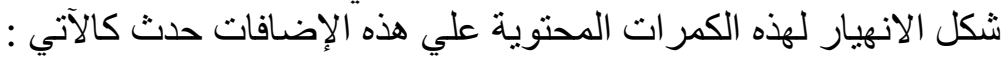

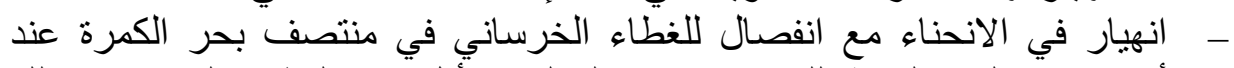

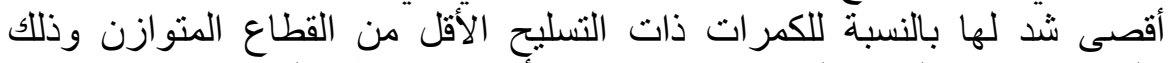

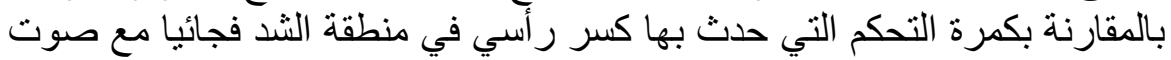

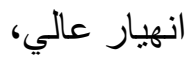

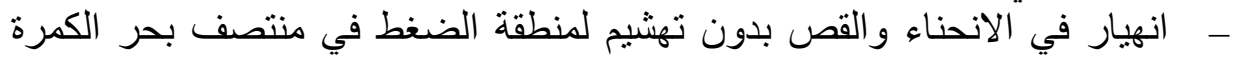

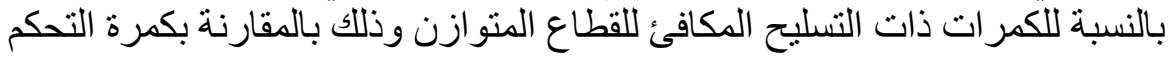

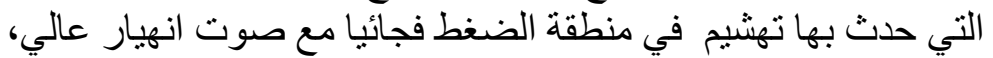

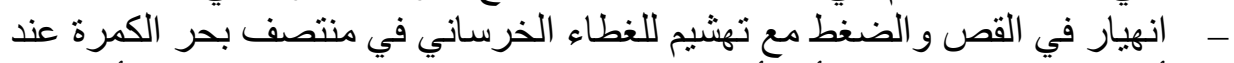

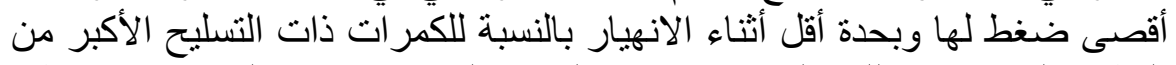

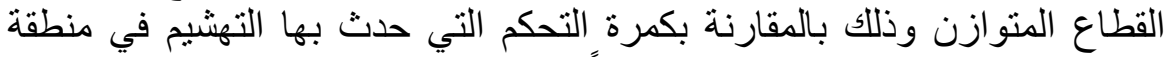
الضغط فجائيا مع صون وذت انهيار عالي جداً. 